MAGDALENA SZUBIELSKA, KATARZYNA PASTERNAK, MARZENA WÓJTOWICZ, ANNA SZYMAŃSKA

Katolicki Uniwersytet Lubelski

\title{
Ocena sztuki osób z niepełnosprawnością wzroku przez dzieci i dorosłych
}

\begin{abstract}
Magdalena Szubielska, Katarzyna Pasternak, Marzena Wójtowicz, Anna Szymańska, Ocena sztuki osób z niepetnosprawnościa wzroku przez dzieci i dorostych [Evaluation of art of people with visual impairment by children and adults]. Interdyscyplinarne Konteksty Pedagogiki Specjalnej, nr 22, Poznań 2018. Pp. 167-183. Adam Mickiewicz University Press. ISSN 2300-391X. DOI: https://doi.org/10.14746/ ikps.2018.22.10
\end{abstract}

The aim of the study was to determine whether the age of the audience of the exhibition influences the assessment of aesthetic preferences of artistic products made up by people with visual impairment. The research was conducted to give an answer if there are differences in the preferences of different categories of artworks created by artists who are blind or low vision. The research consisted in the evaluation of raised-line drawings, photographs, sculptures and the tactile picturebook. These artistic products were presented in the art gallery. The assessments were made on a 5-point scale, where the respondents indicated how much they liked the artworks they were watching. In the study participated 118 people, including 80 children and 38 adults. It turned out that age and type of art had an interactive impact on the aesthetic assessment. Age differences in aesthetic preference were found in reference to drawings and picture books. The visual art created by people with sight impairment was evaluated very positively.

KEY WORDS: visual impairment, visual art, art evaluation, aesthetic preference 


\section{Wprowadzenie}

Przez lata nastawienie do osób z niepełnosprawnością zmieniało się. Z jednej strony okazuje się, że w skali świata postawa społeczeństwa wobec takich osób staje się coraz przychylniejsza i bardziej akceptująca ${ }^{1}$. Z drugiej strony rodzime badania świadczą o tym, że pozytywne postawy wobec osób z niepełnosprawnościami nie są częste wśród Polek i Polaków ${ }^{2}$. Badania prowadzone przez Małgorzatę Orłowską ${ }^{3}$ wskazują, że osoby z dysfunkcjami $\mathrm{w}$ równym stopniu są postrzegane pozytywnie, co i negatywnie. Natomiast $z$ danych pozyskanych przez instytut Badania i Rozwoju Aktywności Społecznej ${ }^{4}$ wynika, że osoby z niepełnosprawnościami postrzegają siebie jako nieprzychylnie odbierane przez społeczeństwo. Odmienne odczucia osób z niepełnosprawnościami od deklaracji społeczeństwa na ich temat mogą wyjaśnić badania Heleny Larkowej ${ }^{5}$. Zwraca ona uwagę na to, że deklarowane postawy ludzi, które są najczęściej pozytywne, są inne niż te niezwerbalizowane, które z kolei są negatywne. Najczęstszą przyczyną niechęci do osób z niepełnosprawnościami są stereotypy, które przejawiają się negatywnym stosunkiem emocjonalnym, mylnymi wyobrażeniami i brakiem wiedzy na temat potrzeb tych osób. Wiedza dotycząca możliwości samodzielnego funkcjonowaniu i potencjału osób z niepełnosprawnością wzroku jest w społe-

${ }^{1} \mathrm{G}$. Berkson, Intellectual and physical disabilities in prehistory and early civilization. „Mental Retardation” 2004, nr 42(3), s. 195-208.

${ }^{2}$ M. Zaorska, E. Andrulonis, Postawy społeczne wobec osób niepetnosprawnych, „Wychowanie na co dzień” 2006, nr 7-8(154-155), s. 20-23.

${ }^{3}$ M. Orłowska, Postawy Polaków wobec osób niepetnosprawnych, „Szkoła Specjalna" 2001, nr 4, s. 208-212.

4 Instytut Badania i Rozwoju Aktywności Społecznej, Wspólnie na rzecz integracji. Diagnoza preferencji, oczekiwań i potrzeb niepetnosprawnych mieszkańców Poznania, 2010. Pozyskano z: http://www.poznan.pl/mim/hc/diagnoza-preferencji-oczekiwan-i-po trzeb-niepelnosprawnych-mieszkancow-poznania,p,22190,22194,22474.html [dostęp: 19.03.2018].

${ }^{5}$ H. Larkowa, Postawy społeczne wobec osób z odchyleniami od normy, [w:] Pedagogika rewalidacyjna, red. A. Hulek, Wydawnictwo PWN, Warszawa 1980, s. 478-491. 
czeństwie dość nikła. Prawdopodobnie dlatego dysfunkcję wzroku uznaje się za jedną z najbardziej zagrażających niepełnosprawności, wiążącą się z zależnością od innych i poczuciem niepewnoścí. Wnioski te popierają badania Kornelii Czerwińskiej ${ }^{7}$ przeprowadzone na młodzieży szkolnej. $W$ teście zdań niedokończonych młodzież w większości pól wpisała negatywne opinie dotyczące osób niewidomych. Badanie to pokazało nikłą wiedzę na temat osób z dysfunkcją wzroku oraz negatywne konsekwencje niewystarczającej edukacji szkolnej na temat niepełnosprawności.

Naturalną potrzebą dzieci jest nawiązywanie relacji z rówieśnikami. Jednakże dzieci z dysfunkcjami mają trudności w nawiązywaniu i podtrzymywaniu przyjaźni. Postawy dzieci w stosunku do kolegów i koleżanek niewidzących stanowią często odbicie postaw prezentowanych przez rodziców i społeczeństwo ${ }^{8}$. Ewa Marzec ${ }^{9}$ na podstawie swych badań wskazuje, że skoro $\mathrm{w}$ dzieciństwie kształtują się wzorce relacji z rówieśnikami, to można to wykorzystać dla przyszłych interakcji z osobami niepełnosprawnymi. Wiadomo, że dzieci przedszkolne niechętnie widziałyby rówieśnika z niepełnosprawnością wzroku jako towarzysza zabaw ${ }^{10}$. Badaniami pozycji socjometrycznej uczniów niewidzących w szkołach ogólnodostępnych zajmowała się Zofia Palak ${ }^{11}$. Na podstawie jej badań można

${ }^{6}$ R. Reina, V. Lopez, M. Jiménez, T. García-Calvo, Y. Hutzler, Effects of awareness interventions on children's attitudes toward peers with a visual impairment, "International Journal of Rehabilitation Research" 2011, nr 34(3), s. 243-248.

${ }^{7} \mathrm{~K}$. Czerwińska, Obraz osób niewidomych w opiniach dzieci w wieku wczesnoszkolnym - komunikat z badań, „Niepełnosprawność i Rehabilitacja” 2011, nr 1, s.46-54.

${ }^{8}$ E. Skoczylas, Dziecko z dysfunkcją wzroku w integracyjnym systemie ksztatcenia, [w:]Uczeń ze specjalnymi potrzebami edukacyjnymi w środowisku rówieśniczym, red. E. Domagała-Zyśk, Wydawnictwo KUL, Lublin 2012, s. 93-110.

${ }^{9}$ E. Marzec, Modyfikacja postaw wobec osób z dysfunkcja wzroku, [w:] Postawy wobec niepetnosprawności, red. L. Frąckiewicz, Wydawnictwo Uczelniane AE, Katowice 2002, s. 63-78.

${ }^{10}$ S.-Y. Hong, K.-A. Kwon, H.-J. Jeon, Children's attitudes towards peers with disabilities: Associations with personal and parental factors, "Infant and Child Development” 2014, nr 23(2), s. 170-193.

${ }^{11}$ Z. Palak, Uczniowie niewidomi i stabowidzacy w szkołach ogólnodostępnych, Wydawnictwo UMCS, Lublin 2000, s. 155. 
wskazać, że: jedynie 20\% dzieci z uszkodzonym wzrokiem jest akceptowanych przez grupę rówieśniczą. Większość z dzieci niewidomych $(63,3 \%)$ znajduje się w niekorzystnej społecznie sytuacji: $33,3 \%$ badanych uczniów niewidomych i słabowidzących jest izolowanych przez pełnosprawnych rówieśników, a 30\% z nich doświadcza odrzucenia. Z kolei badania Mirosławy Zielińskiejej przeprowadzone wśród uczniów z liceum z jednej strony wskazują na częste $(68,2 \%)$ deklarowanie pozytywnego nastawienia do rówieśników z dysfunkcjami, z drugiej zaś strony - na rzadkie (22\%) deklaracje gotowości zaprzyjaźnienia się z niepełnoprawnym kolegą. Porównawcze badania nad postawami studentów z Holandii i Polski13 wskazują, że nasi rodacy są mniej tolerancyjni wobec osób z niepełnosprawnościami, co wynika ze złych doświadczeń w interakcjach z osobami niepełnosprawnymi lub z ich brakiem. Podsumowując, przytoczone badania wskazują na to, że pomimo iż stosunek wobec osób z dysfunkcjami zmienia się i jest coraz pozytywniejszy, to $\mathrm{w}$ dalszym wynikające $\mathrm{z}$ braku wiedzy stereotypy sprawiają, że zarówno dzieci, jak i dorośli niechętnie utrzymują kontakty $\mathrm{z}$ osobami $\mathrm{z}$ niepełnosprawnościami. Tymczasem zmiana postaw może dokonać się dzięki interwencjom uświadamiającym. Badaniem zmiany postaw wśród uczniów z gimnazjum zajmował się Andrzej Pielecki14. W jego badaniach najskuteczniejszą metodą przekazywania wiedzy i zmiany postaw okazały się projekcie filmowe, a największy wzrost wiedzy po interwencji uświadamiającej odnotowywano w odniesieniu do dysfunkcji sensorycznych (wzrok, słuch).

Osoby słabowidzące i niewidome mogą samodzielnie poruszać się po mieście, założyć rodzinę, mieć sukcesy w życiu zawodowym,

12 M. Zielińska, Postawy młodzieży licealnej wobec nie-petnosprawnych rówieśników, Wyższa Szkoła Pedagogiczna im. T. Kotarbińskiego w Zielonej Górze, niepublikowana praca magisterska, Zielona Góra 2000.

13 B. Papuda-Dolińska,Postawy wobec osób z niepetnosprawnością: na podstawie opinii polskich $i$ holenderskich studentów, „Przegląd Naukowo-Metodyczny. Edukacja dla Bezpieczeństwa" 2012, nr 4, s.129-143.

14 A. Pielecki, Zmiany postaw młodzieży wobec osób niepetnosprawnych, Wydawnictwo Uniwersytetu Marii Curie-Skłodowskiej, Lublin 2013. 
ale także realizować się twórczo. Co zaskakujące, obszarem tej twórczości często stają się tzw. sztuki wizualne15, a wybieranym medium artystycznym są m.in. rysunki wypukłe (za pierwszych propagatorów poglądu, że nawet osoby niewidome od urodzenia mogą rysować, można uznać Johna Keneddy'ego'16 - na arenie międzynarodowej oraz Wandę Szuman - na gruncie polskim) ${ }^{17}$, rzeźby $^{18}$ czy zdjęcia ${ }^{19}$.

Z badań wynika, że odbiór prac plastycznych artystów z niepełnosprawnościami wzroku jest nadmiernie pozytywny - jakby widzowie nie wierzyli w możliwości autorów i akceptowali je nie ze względu na fakt, że im się podobają, ale ze względu na to, że stworzono je bez udziału wzroku, co można określić jako odbiór poprzez stereotyp niepełnosprawności twórcy ${ }^{20}$. Taki stereotypowy odbiór ujawnia się już na etapie samego oglądania pracy, co wykazano w badaniach okulograficznych: siła korelacji czasów fiksacji wzroku $\mathrm{w}$ tych samych regionach zainteresowania $\mathrm{u}$ osób badanych przekonanych o niepełnosprawności twórcy zdjęcia była wyższa, niż u osób, którym nie powiedziano nic o niepełnosprawności fotografa ${ }^{21}$. W znanych nam badaniach dotyczących percepcji estetycznej poprzez stereotyp niepełnosprawności autora ani Ewa Niestorowicz ${ }^{22}$,

15 M. Szubielska, E. Niestorowicz, Sztuki wizualne oczami niewidomych, „Fragile” 2017, nr 1(35), s. 36-40.

16 J.M. Kennedy, Drawing and the blind: Pictures to touch, CT: Yale University Press, New Haven 1993, s. 95-126.

17 W. Szuman, O dostępności rysunku dla dzieci niewidomych, Państwowe Zakłady Wydawnictw Szkolnych, Warszawa 1967, s. 5-139.

18 E. Niestorowicz, Świat w umyśle i rzeźbie osób głuchoniewidomych, Wydawnictwo Uniwersytetu Marii Curie-Skłodowskiej, Lublin 2007, s. 38-40.

19 J. Rothenstein, The Blind Photographer: 150 Extraordinary Photographs from Around the World, Princeton Architectural Press, London 2016.

20 E. Niestorowicz, op. cit., s. 231-235.

${ }^{21}$ M. Szubielska, B. Bałaj, A. Fudali-Czyż, Estetyczny odbiór fotografii poprzez stereotyp umysłowej niepetnosprawności twórcy, "Psychologia Społeczna” 2012, nr 23(4), s. 372-378. - w badaniach tych autorki badały jednak nie stereotyp osoby $\mathrm{z}$ niepełnosprawnością wzroku, ale $\mathrm{z}$ niepełnosprawnością intelektualną.

22 E. Niestorowicz, op. cit., s. 231-235. 
ani Magdalena Szubielska z zespołem ${ }^{23}$ nie eksponowały osobom badanym oryginalnych wytworów artystycznych, a jedynie ich reprodukcje $\mathrm{w}$ formie fotografii. Interesowało nas, jaki jest odbiór sztuki wykonanej przez osoby niewidome i słabowidzące, prezentowanej $\mathrm{w}$ prawdziwej galerii. $\mathrm{W}$ takiej sytuacji widzowie mają szansę kontemplować odpowiednio wyeksponowane oryginały wytworów artystycznych, które za sprawą umieszczenia ich w przestrzeni wystawienniczej otrzymały rangę dzieła sztuki.

Celem badania, które przeprowadzono na wystawie prac osób niewidomych i słabowidzących, było ustalenie: Czy wiek odbiorców wystawy wpływa na ocenę preferencji estetycznej dzieł stworzonych przez osoby niewidome i słabowidzące, a także: Czy istnieją różnice w preferencji różnych kategorii wytworów artystycznych autorstwa osób z niepełnosprawnościami wzroku?

\section{Badanie - metoda}

W badaniu wzięło udział 118 osób, w tym 80 dzieci (od 5 do 7 lat) z lubelskich szkół i przedszkoli oraz 38 osób dorosłych (w wieku od 18 do 22 lat) - studentek i studentów psychologii. Szczegółowe informacje dotyczące wieku, płci i liczebności poszczególnych grup wiekowych zawiera tabela 1 . Udział w badaniu był dobrowolny. Rodzice wszystkich dzieci wyrazili pisemną zgodę na udział potomstwa w badaniu.

Tabela 1. Charakterystyka osób badanych

\begin{tabular}{|l|c|c|c|c|}
\hline & 5-latki & 6-latki & 7-latki & Dorośli \\
\hline Liczebność & 22 & 33 & 25 & 38 \\
\hline Liczebność kobiet & 7 & 16 & 13 & 33 \\
\hline Liczebność mężczyzn & 15 & 17 & 12 & 5 \\
\hline Wiek: średnia arytmetyczna & 5,20 & 6,09 & 7,04 & 19,71 \\
\hline Wiek: odchylenie standardowe & 0,25 & 0,20 & 0,14 & 0,73 \\
\hline
\end{tabular}

${ }^{23}$ M. Szubielska, B. Bałaj, A. Fudali-Czyż, op. cit. 
Przedmiotem oceny była wystawa „Miasto, którego nie widać”, prezentowana w Galerii Labirynt w Lublinie między 19 grudnia 2017 r. a 28 lutego 2018 r. (zob. rys. 1). Autorami i autorkami prac były osoby z niepełnosprawnościami wzroku - uczniowie i uczennice Specjalnego Ośrodka Szkolno-Wychowawczego dla Dzieci i Młodzieży Niepełnosprawnych im. Prof. Zofii Sękowskiej w Lublinie. Na wystawie eksponowano 12 rysunków wypukłych na foliach (tytuły prac to: "Teatr NN", „Wieżowiec Pekin”, "Spacer”, „Louis Braille i Selena Gomez. Para w mieście”, "Dworzec Główny PKP Kunickiego”, „Spróbuj się nie przewrócić”, ,Szkoła”, „Brama Krakowska”, „Odpoczynek”, „Autobus”, „Wyścigowa”, „Budynek wielofunkcyjny"), cykl 12 czarno-białych zdjęć wykonanych analogowym aparatem Kiev (pod wspólnym tytułem "Miasto, którego nie widać"), 8 małych nieszkliwionych rzeźb ceramicznych (tytuły prac to: „Fontanna”, „Pekin”, ,Para na spacerze”, ,Lalka”, „Po prostu wieża”, „Odpoczynek na ławce”, „Najnowszy iPhone”, ,Autobus”)

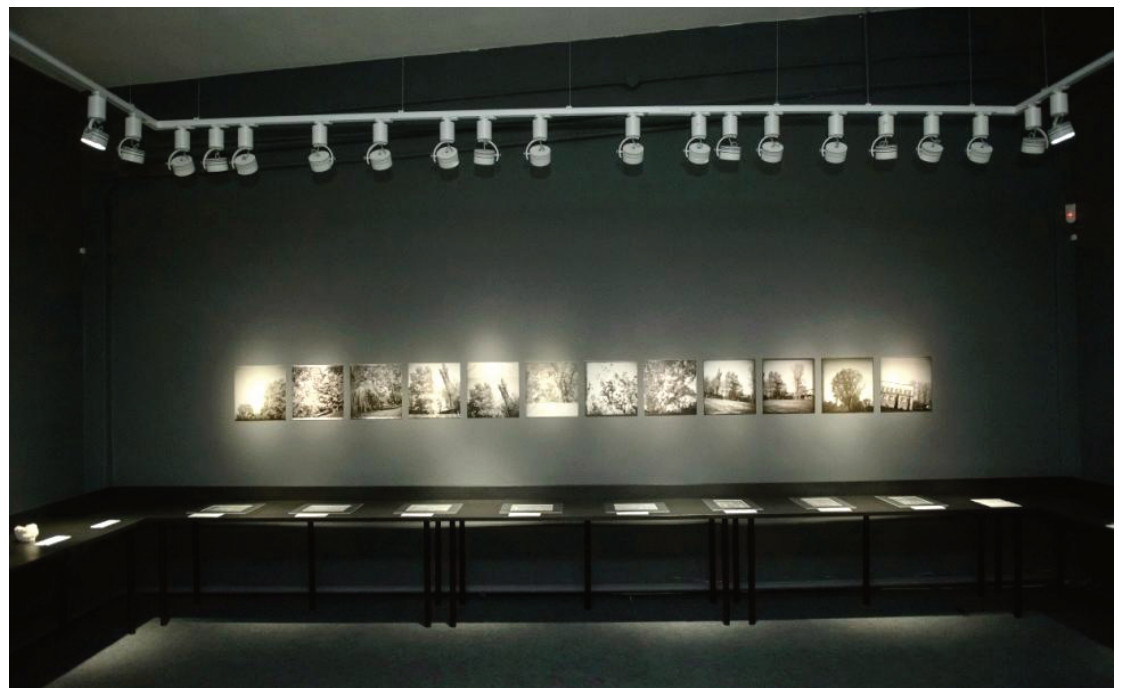

Rys. 1. Widok wystawy „Miasto, którego nie widać” (fot. Wojciech Pacewicz, dzięki uprzejmości Galerii Labirynt w Lublinie) 
oraz dotykową książkę obrazkową "Miasto, którego nie widać” zawierającą historie dotyczące życia w mieście (napisane na maszynie brajlowskiej) oraz ilustracje w technice kolażu. Wszystkie prace powstały w $2017 \mathrm{r}$.

Osoby badane oglądały wystawę w małych grupach, bez czytania informacji kuratorskiej, a także bez żadnych wskazówek ze strony edukatorów pracujących w galerii lub osób pilnujących ekspozycji (w razie pytań podawano informację, że odpowiedzi na nie zostaną udzielone po obejrzeniu całej wystawy i dokonaniu jej oceny). Przed rozpoczęciem oglądania badanym powiedziano jedynie, że tytuł wystawy brzmi „Miasto, którego nie widać” i że jej autorami i autorkami są osoby niewidome i słabowidzące (dzieciom wyjaśniano dodatkowo, że są to osoby, które nie widzą w ogóle albo widzą bardzo słabo). Po obejrzeniu wystawy znajdujące się na niej prace były oceniane przez każde dziecko na arkuszu odpowiedzi. Arkusz zawierał rysunkową skalę preferencji, składającą się z pięciu emotikonów rozmieszczonych w rzędzie w kolejności od zdecydowanie uśmiechniętego (po lewej) do zdecydowanie niezadowolonego (po prawej). Zadaniem osób badanych było kolejno zakreślenie emotikonu, który najlepiej odzwierciedlał to, w jakim stopniu podobały im się oglądane na wystawie: rysunki, zdjęcia, rzeźby oraz książka obrazkowa. Badanym podawano kolejno następujące instrukcje: "Zaznacz, w jakim stopniu podobały Ci się oglądane rysunki”, "Zaznacz, w jakim stopniu podobały Ci się oglądane zdjęcia”, "Zaznacz, w jakim stopniu podobały Ci się oglądane rzeźby”, "Zaznacz, w jakim stopniu podobała Ci się oglądana książka”. Każde $\mathrm{z}$ dzieci samodzielnie (lub z niewielką pomocą osoby prowadzącej badanie) zaznaczało wybrany emotikon, jako odpowiedź na każde z tych pytań.

Zmiennymi niezależnymi w badaniu były: (1) wiek (5-latki, 6-latki, 7-latki, dorośli) oraz (2) Rodzaj Wytworu Artystycznego (rysunki, fotografie, rzeźby, książka obrazkowa). Jako zmienną zależną badano ocenę wystawy na wymiarze preferencji estetycznej, której wskaźnik, wyrażony wybranym emotikonem, stanowił stopień $\mathrm{w}$ jakim odbiorcom podobały się prace prezentowane na wystawie. 


\section{Badanie - wyniki}

Analizę danych prowadzono $\mathrm{z}$ wykorzystaniem programu SPSS. Odpowiedzi osób badanych zakodowano w postaci liczbowej, przypisując rysunkowej skali wartości od 1 do 5 (1 - buźce zdecydowanie niezadowolonej, 5 - buźce zdecydowanie zadowolonej). Statystyki opisowe ocen poszczególnych kategorii prac przez widzów w różnym wieku zawiera tabela 2.

Dla zmiennej zależnej preferencja estetyczna wykonano mieszaną analizę wariancji z czynnikiem wewnątrzobiektowym - Rodzaj Wytworu Artystycznego i czynnikiem międzyobiektowym - Wiek. Stwierdzono istotny statystycznie efekt główny czynnika Rodzaj

Tabela 2. Ocena rysunków, fotografii, rzeźb i książki obrazkowej przez dzieci w różnym wieku i dorosłych - statystyki opisowe

\begin{tabular}{|c|c|c|c|}
\hline $\begin{array}{c}\text { Rodzaj wytworu } \\
\text { artystycznego }\end{array}$ & Grupa wiekowa & $\begin{array}{c}\text { Ocena: średnia } \\
\text { arytmetyczna }\end{array}$ & $\begin{array}{c}\text { Ocena: odchylenie } \\
\text { standardowe }\end{array}$ \\
\hline \multirow{4}{*}{ Rysunki } & 5-latki & 4,68 & 0,57 \\
\cline { 2 - 4 } & 6-latki & 4,39 & 1,06 \\
\cline { 2 - 4 } & 7-latki & 4,28 & 0,89 \\
\hline \multirow{4}{*}{ Fotografie } & Dorośli & 3,95 & 0,93 \\
\cline { 2 - 4 } & 5-latki & 4,27 & 1,20 \\
\cline { 2 - 4 } & 6-latki & 4,12 & 1,19 \\
\hline \multirow{4}{*}{ Rzeźby } & 7-latki & 4,00 & 1,04 \\
\cline { 2 - 4 } & Dorośli & 4,13 & 1,04 \\
\cline { 2 - 4 } & 5-latki & 4,64 & 0,73 \\
\cline { 2 - 4 } & 6-latki & 4,30 & 1,05 \\
\cline { 2 - 4 } & 7-latki & 4,56 & 0,82 \\
\cline { 2 - 4 } & Dorośli & 4,34 & 0,91 \\
\cline { 2 - 4 } & 5-latki & 4,00 & 1,54 \\
\cline { 2 - 4 } & 6-latki & 3,88 & 1,52 \\
\cline { 2 - 4 } & 7-latki & 3,48 & 0,83 \\
\hline
\end{tabular}


Wytworu Artystycznego, F(2,64, 301,10) = 5,90, p = 0,001, $\eta^{2}=0,05$ oraz istotną interakcję czynników Rodzaj Wytworu Artystycznego i Wiek, $F(7,92,301,10)=2,48, p=0,013, \eta^{2}=0,06$. Efekt główny czynnika Wiek nie był istotny statystycznie, $F(3,14)=0,92, p=0,434$. W związku z otrzymaną interakcją policzono efekty proste, analizując różnice $\mathrm{w}$ ocenie poszczególnych rodzajów prac $\mathrm{u}$ widzów $\mathrm{w}$ danym wieku (cztery jednoczynnikowe analizy wariancji z powtórzonym pomiarem, prowadzone $\mathrm{w}$ grupie dzieci 5-letnich, 6-letnich, 7-letnich oraz w grupie osób dorosłych), a także analizując różnice wiekowe w ocenie wytworów artystycznych należących do danej kategorii dzieł (cztery jednoczynnikowe analizy wariancji, prowadzone dla oceny: rysunków, fotografii, rzeźb, książki obrazkowej).

$\mathrm{W}$ analizach wariancji $\mathrm{z}$ powtórzonym pomiarem nie stwierdzono efektu głównego czynnika Rodzaj Wytworu Artystycznego ani $\mathrm{w}$ grupie widzów 5-letnich, $\mathrm{F}(2,11,44,24)=2,53, \mathrm{p}=0,089$, ani 6-letnich, $\mathrm{F}(3,96)=1,37$, $\mathrm{p}=0$,256. Istotny statystycznie efekt główny czynnika Rodzaj Wytworu Artystycznego stwierdzono natomiast $\mathrm{w}$ grupie odbiorców 7-letnich, $\mathrm{F}(3,72)=5,31, \mathrm{p}=0,004, \mathrm{\eta}^{2}=0,17$, a także osób dorosłych, $\mathrm{F}(3,111)=3,09, \mathrm{p}=0,030, \mathrm{\eta}^{2}=0,08$. Na podstawie wyników testów post-hoc Bonferroniego ustalono, że 7-latkom istotnie bardziej podobały się rzeźby niż książka obrazkowa (istotność testu post-hoc: $\mathrm{p}=0,020$, zob. tab. 2); pozostałe porównania parami $\mathrm{w}$ tej grupie badanych nie były istotne statystycznie. Z kolei widzom dorosłym istotnie mniej podobały się rysunki niż: rzeźby (istotność testu post-hoc: $\mathrm{p}=0,032$, zob. tab. 2) i książka obrazkowa (istotność testu post-hoc: $\mathrm{p}=0,025$, zob. tab. 2); pozostałe porównania parami $\mathrm{w}$ tej grupie badanych nie były istotne statystycznie.

W jednoczynnikowych analizach wariancji nie stwierdzono efektu głównego czynnika Wiek ani w ocenie zdjęć, $\mathrm{F}(3,114)=0,23$, $\mathrm{p}=0,873$, ani rzeźb, $\mathrm{F}(3,114)=0,90, \mathrm{p}=0,446$. Z kolei Wiek istotnie różnicował zarówno ocenę rysunków, $\mathrm{F}(3,114)=3,32, \mathrm{p}=0,022$, $\eta^{2}=0,08$, jak i ocenę książki obrazkowej, $\mathrm{F}(3,114)=2,81, \mathrm{p}=0,043$, $\eta^{2}=0,07$. Na podstawie wyników testów post-hoc Bonferroniego stwierdzono następujące istotne różnice w ocenie prac: rysunki były bardziej preferowane przez dzieci 5-letnie niż dorosłych $(\mathrm{p}=0,018$, 
zob. tab. 2); książka obrazkowa bardziej podobała się widzom dorosłym niż 7-letnim ( $p=0,033$, zob. tab. 2).

$\mathrm{W}$ celu ustalenia, czy oceny prac oglądanych na wystawie istotnie różnią się od oceny środkowej na skali odpowiedzi (tj. ani pozytywnej, ani negatywnej) w poszczególnych grupach odbiorców, policzono 16 testów t dla jednej próby z wartością testowaną równą 3. Wyniki wszystkich testów zamieszczono w tabeli 3. Jedynie w przypadku oceny książki obrazkowej przez 7-latków nie stwierdzono istotnej statystycznie różnicy między oceną uzyskaną $\mathrm{w}$ badaniu a oceną środkową zastosowanej skali pomiarowej (którą można określić jako neutralną). W przypadku pozostałych ocen były one istotnie wyższe od oceny neutralnej (zob. tab. 2).

Tabela 3. Wyniki testu t dla jednej próby dla oceny rysunków, fotografii, rzeźb i książki obrazkowej przez dzieci w różnym wieku i dorosłych (różnice istotne statystycznie zaznaczono " $\left.{ }^{* \prime \prime}\right)$

\begin{tabular}{|l|c|c|}
\hline $\begin{array}{c}\text { Rodzaj wytworu } \\
\text { artystycznego }\end{array}$ & Grupa wiekowa & Wynik testu \\
\hline \multirow{4}{*}{ Rysunki } & 5-latki & $\mathrm{t}(21)=13,89, \mathrm{p}<0,001^{*}$ \\
\cline { 2 - 3 } & 6-latki & $\mathrm{t}(32)=7,56, \mathrm{p}<0,001^{*}$ \\
\cline { 2 - 3 } Fotografie & 7-latki & $\mathrm{t}(24)=7,19, \mathrm{p}<0,001^{*}$ \\
\hline & Dorośli & $\mathrm{t}(37)=6,29, \mathrm{p}<0,001^{*}$ \\
\cline { 2 - 3 } & 5-latki & $\mathrm{t}(21)=4,97, \mathrm{p}<0,001^{*}$ \\
\cline { 2 - 3 } & 6-latki & $\mathrm{t}(32)=5,40, \mathrm{p}<0,001^{*}$ \\
\cline { 2 - 3 } Rzeźby & 7-latki & $\mathrm{t}(24)=4,80, \mathrm{p}<0,001^{*}$ \\
\cline { 2 - 3 } & Dorośli & $\mathrm{t}(37)=6,68, \mathrm{p}<0,001^{*}$ \\
\cline { 2 - 3 } & 5-latki & $\mathrm{t}(21)=10,56, \mathrm{p}<0,001^{*}$ \\
\cline { 2 - 3 } & 6-latki & $\mathrm{t}(32)=7,16, \mathrm{p}<0,001^{*}$ \\
\hline \multirow{5}{*}{ Książka obrazkowa } & 7-latki & $\mathrm{t}(24)=9,51, \mathrm{p}<0,001^{*}$ \\
\cline { 2 - 3 } & Dorośli & $\mathrm{t}(37)=9,10, \mathrm{p}<0,001^{*}$ \\
\cline { 2 - 3 } & 5-latki & $\mathrm{t}(21)=3,04, \mathrm{p}<0,001^{*}$ \\
\cline { 2 - 3 } & 6-latki & $\mathrm{t}(32)=3,33, \mathrm{p}=0,002^{*}$ \\
\cline { 2 - 3 } & 7-latki & $\mathrm{t}(24)=1,63, \mathrm{p}=0,117$ \\
\hline
\end{tabular}




\section{Badanie - dyskusja wyników}

Celem badania było rozstrzygnięcie dwóch pytań: (1) Czy ocena estetyczna sztuki stworzonej przez osoby $\mathrm{z}$ niepełnosprawnością wzroku zmienia się wraz z wiekiem widzów (badano dzieci w wieku 5-7 lat oraz młodych dorosłych); (2) Czy ocena estetyczna zależy od kategorii oglądanych wytworów artystycznych (pod uwage wzięto rysunki wypukłe wykonane na specjalnych foliach, czarno-białe fotografie, nieszkliwione rzeźby ceramiczne oraz książkę obrazkową zawierającą teksty i dotykowe kolaże).

Stwierdzono, że ocena dzieł wizualnych wykonanych przez osoby niewidome i słabowidzące w sposób istotny zależy od interakcji czynników: wiek i rodzaj wytworu artystycznego. Innymi słowy - to czy i w jaki sposób wraz z wiekiem zmieniają się preferencje estetyczne, zależy od tego, czy przedmiot oceny stanowią rysunki, fotografie, rzeźby czy też książka obrazkowa, które wykonały osoby z niepełnosprawnościami wzroku.

Oceny estetyczne dzieci 5-letnich oraz 6-letnich nie zależały od rodzaju ocenianego wytworu artystycznego. Może to świadczyć o tym, że dzieci w wieku 5 i 6 lat wszystkie prace eksponowane na wystawie odbierały równie entuzjastycznie - być może z uwagi na fakt, że sama wizyta $\mathrm{w}$ galerii sztuki była dla nich dużym przeżyciem. Tymczasem preferencje dzieł zarówno u dzieci 7-letnich, jak i u osób dorosłych zależały od tego, jaka kategoria wytworu artystycznego była poddawana ocenie. 7-latkom istotnie bardziej podobały się rzeźby niż książka obrazkowa. Z kolei widzom dorosłym istotnie mniej podobały się rysunki niż rzeźby i książka obrazkowa. Ponadto ustalono, że zarówno ocena zdjęć, jak i rzeźb nie zmieniała się istotnie wraz z wiekiem odbiorców. Różnice wiekowe w preferencji estetycznej stwierdzono natomiast $\mathrm{w}$ odniesieniu do rysunków i książki obrazkowej. Rysunki istotnie bardziej podobały się 5-latkom niż widzom dorosłym. Ze względu na opóźnienie w rozwoju rysunkowym osób niewidomych względem osób widzących ${ }^{24}$

${ }_{24}$ M. Szubielska, E. Niestorowicz, B. Marek, Jak rysują osoby, które nigdy nie widziały? Badania niewidomych uczniów / Drawing without eyesight. Evidence from congeni- 
rysunki autorów niewidzących w aspekcie formalnym przypominają rysunki małych dzieci, które z kolei podobne są do tzw. abstrakcji geometrycznych tworzonych przez artystów nowoczesnych i współczesnych. W eksperymencie nad odbiorem sztuki abstrakcyjnej z udziałem dzieci ${ }^{25}$ stwierdzono, że bardziej podobają im się prace autorstwa ich rówieśników niż profesjonalnych artystów. Podobieństwo prac wykonanych przez osoby niewidome do dziecięcych szkiców może wyjaśniać wyższą preferencję rysunków wykonanych przez osoby niewidome $\mathrm{w}$ grupie najmłodszych $\mathrm{z}$ badanych dzieci, względem preferencji widzów dorosłych. Z kolei książka obrazkowa istotnie bardziej przypadła do gustu osobom dorosłym niż 7-latkom. Może to wynikać z tego, że dorośli widzowie wystawy w odbiorze książki dotykowej bardziej skupili się na treści tekstów, niż na ilustrujących je kolażach, zaś dzieci - na ilustracjach (większość z nich nie potrafiła jeszcze czytać). Historie zawarte w książce traktowały głównie o problemach życia w mieście osoby, która nie widzi, o dezorientacji przestrzennej czy zgubieniu drogi i związanych z tym lękach. Kolaże zamieszczone w książce w przeważającej mierze można określić jako „dziecinne” - były one podobne do ilustracji, które można spotkać w większości książek dla małych dzieci. Prawdopodobne jest, że dorośli odbiorcy docenili opowieści osób z niepełnosprawnością wzroku, zaś najstarszej grupie spośród badanych dzieci ilustracje nie podobały się, ponieważ były zbyt infantylne.

Warte podkreślenia jest to, że niemal wszystkie oceny wytworów artystycznych osób z niepełnosprawnościami wzroku przez widzów dziecięcych i dorosłych można uznać za pozytywne. Wyjątek stanowi ocena obrazkowej książki dokonana przez 7-latki, którą można określić jako neutralną (ani pozytywną, ani negatywną). Zastanawiające jest to, czy tak wysokie noty wynikają ze stereoty-

tally blind learners, "Roczniki Psychologiczne// Annals of Psychology" 2016, nr 19(4), s. 659-700.

${ }^{25} \mathrm{~J}$. Nissel, A. Hawley-Dolan, E. Winner, Can young children distinguish abstract expressionist art from superficially similar works by preschoolers and animals?, „Journal of Cognition and Development" 2016, nr 17(1), s.18-29. 
powego spojrzenia na twórczość osób z niepełnosprawnością wzroku. Odbiorca może mieć przekonanie, że artystom, którzy nie widzą, trudniej jest coś stworzyć w obszarze sztuk wizualnych, dlatego jeśli już tego dokonali, oceniani są nadmiernie pozytywnie, z "poprawką" na niepełnosprawność. A może wysokie oceny wytworów artystycznych wynikały raczej z tego, że były one prezentowane w prawdziwej galerii sztuki, gdzie na co dzień wystawiane są prace uznanych współczesnych artystów wizualnych? Wiadomo, że kontekst przestrzeni wystawienniczej podwyższa ocenę sztuki²6, ponieważ umieszczenie prac $\mathrm{w}$ galerii czy muzeum nobilituje dzieło. Hipotezy dotyczące tego, czy na odbiór sztuki osób niewidomych i słabowidzących wpływa raczej koncentracja na niepełnosprawności autora, czy też umieszczenie prac w przestrzeni galerii, warte są weryfikacji w kolejnych eksperymentach nad odbiorem sztuki osób z niepełnosprawnościami.

\section{Podsumowanie}

Zarówno dzieci, jak i dorośli pozytywnie odebrali niemal wszystkie prace prezentowane na wystawie, której autorami i autorkami były osoby niewidome i słabowidzące (aczkolwiek zaobserwowano też różnice $\mathrm{w}$ preferencjach ze względu na wiek i rodzaj wytworu artystycznego - niektóre prace oceniane były w poszczególnych grupach dziecięcych odbiorców i dorosłych dobrze, inne zaś bardzo dobrze). Wynik ten może być traktowany jako argument za potrzebą organizowania kolejnych tego typu wystaw - dzięki podobnym inicjatywom osoby widzące będą miały szansę dowiedzieć się, jakie są możliwości twórcze artystów-amatorów z niepełnosprawnością wzroku, a dzięki temu być może także zmienią swoje nastawienie wobec tych, którzy żyją bez zmysłu wzroku. Takie przedsięwzięcia mogą działać na odbiorców na zasadzie interwencji uświadamiają-

${ }^{26}$ D. Brieber, M. Nadal, H. Leder, In the white cube: Museum context enhances the valuation and memory of art, "Acta Psychologica” 2014, nr 154, s. 36-42. 
cej $^{27}$, rozszerzając poza obszar edukacji szkolnej (co okazywało się w warunkach polskich skuteczne28) możliwość edukowania społeczeństwa na temat niepełnosprawności.

Ciekawe, że różnice w preferencji poszczególnych kategorii wytworów artystycznych: rysunków, rzeźb, fotografii i książki, ujawniły się dopiero $\mathrm{u}$ dzieci siedmioletnich, a więc u dzieci, które uczęszczają do szkoły, zaś młodszym dzieciom w zbliżonym stopniu podobały się dzieła tworzone w różnych technikach. Trudno stwierdzić, czy otrzymany efekt ma związek z rozwojem poznawczym i estetycznym dziecka, czy też z edukacją plastyczną prowadzoną w młodszych klasach szkoły podstawowej. Zagadnienie to warto rozstrzygnąc w kolejnych badaniach empirycznych dotyczących percepcji estetycznej sztuki przez dzieci.

Nie bez znaczenia jest także to, że działania w obszarze sztuk wizualnych mogą stymulować rozwój poznawczy, społeczny i emocjonalny osób niewidomych ${ }^{29}$. Wydaje się, że twórczość w obszarze sztuk wizualnych może uwrażliwiać artystę, który nie widzi, na wizualno-przestrzenne aspekty otoczenia, w którym się znajduje lub które zamierza zobrazować, a tym samym przyczyniać się do rozwoju wyobraźni przestrzennej. W praktyce ma szansę przełożyć się to na lepszą orientację przestrzenną i swobodę w samodzielnym poruszaniu się. Paradoksalnie więc działalność w obszarze, który wydawać się może zupełnie nieodpowiedni dla osoby pozbawionej wzroku, może przyczynić się do poprawy jej jakości życia.

\section{Bibliografia}

Berkson G., Intellectual and physical disabilities in prehistory and early civilization. „Mental Retardation" 2004, nr 42(3).

${ }^{27}$ R. Reina, V. Lopez, M. Jiménez, T. García-Calvo, Y. Hutzler, Effects of awareness interventions on children's attitudes toward peers with a visual impairment, "International Journal of Rehabilitation Research" 2011, nr 34(3), s. 243-248.

28 A. Pielecki, op. cit.

${ }^{29}$ M. Szubielska, E. Niestorowicz, op. cit., s. 89-104. 
Brieber D., Nadal M., Leder H., In the white cube: Museum context enhances the valuation and memory of art, "Acta Psychologica” 2014, nr 154.

Czerwińska K., Obraz osób niewidomych w opiniach dzieci w wieku wczesnoszkolnym komunikat z badań, „Niepełnosprawność i Rehabilitacja” 2011, nr 1.

Hong S.-Y., Kwon K.-A., Jeon H.-J., Children's attitudes towards peers with disabilities: Associations with personal nd parental factors, "Infant and Child Development" 2014, nr 23(2).

Kennedy J.M., Drawing and the blind: Pictures to touch, CT: Yale University Press, New Haven 1993.

Larkowa H., Postawy społeczne wobec osób z odchyleniami od normy, [w:] Pedagogika rewalidacyjna, red. A. Hulek, Wydawnictwo PWN, Warszawa 1980.

Marzec E., Modyfikacja postaw wobec osób z dysfunkcja wzroku, [w:] Postawy wobec niepetnosprawności, red. L. Frąckiewicz, Wydawnictwo Uczelniane AE, Katowice 2002.

Niestorowicz E., Świat w umyśle i rzeźbie osób głuchoniewidomych, Wydawnictwo Uniwersytetu Marii Curie-Skłodowskiej, Lublin 2007.

Nissel J., Hawley-Dolan A.,Winner E., Can young children distinguish abstract expressionist art from superficially similar works by preschoolers and animals?, „Journal of Cognition and Development" 2016, nr 17(1).

Orłowska M., Postawy Polaków wobec osób niepetnosprawnych, „Szkoła Specjalna” 2001, nr 4.

Palak Z., Uczniowie niewidomi i słabowidzący w szkołach ogólnodostępnych, Wydawnictwo UMCS, Lublin 2000.

Papuda-Dolińska B., Postawy wobec osób z niepetnosprawnością: na podstawie opinii polskich i holenderskich studentów, „Przegląd Naukowo-Metodyczny. Edukacja dla Bezpieczeństwa" 2012, nr 4.

Pielecki A., Zmiany postaw młodzieży wobec osób niepetnosprawnych, Wydawnictwo Uniwersytetu Marii Curie-Skłodowskiej, Lublin 2013.

Reina R., Lopez V., Jiménez M., García-Calvo T., Hutzler Y., Effects of awareness interventions on children's attitudes toward peers with a visual impairment, "International Journal of Rehabilitation Research" 2011, nr 34(3).

Rothenstein J., The Blind Photographer: 150 Extraordinary Photographs from Around the World, Princeton Architectural Press, London 2016.

Skoczylas E., Dziecko z dysfunkcja wzroku w integracyjnym systemie ksztatcenia, [w:] Uczeń ze specjalnymi potrzebami edukacyjnymi w środowisku rówieśniczym, red. E. Domagała-Zyśk, Wydawnictwo KUL, Lublin 2012.

Szubielska M., Bałaj B., Fudali-Czyż A., Estetyczny odbiór fotografii poprzez stereotyp umystowej niepetnosprawności twórcy, „Psychologia Społeczna” 2012, nr 23(4).

Szubielska M., Niestorowicz E., Twórczość plastyczna jako forma wspierania rozwoju osób niewidomych i głuchoniewidomych, [w:] Rozwój i jego wspieranie w perspektywie rehabilitacji i resocjalizacji, red. D. Múller, A. Sobczak, Wydawnictwo Uniwersytetu Łódzkiego, Łódź 2013. 
Szubielska M., Niestorowicz E., Sztuki wizualne oczami niewidomych, „Fragile” 2017, nr 1(35), s. 36-40.

Szubielska M., Niestorowicz E., Marek B., Jak rysuja osoby, które nigdy nie widziaty? Badania niewidomych uczniów / Drawing without eyesight. Evidence from congenitally blind learners, "Roczniki Psychologiczne// Annals of Psychology" 2016, nr 19(4).

Szuman W., O dostępności rysunku dla dzieci niewidomych, Państwowe Zakłady Wydawnictw Szkolnych, Warszawa 1967.

Zaorska, M., Andrulonis, E. Postawy społeczne wobec osób niepetnosprawnych. „Wychowanie na co dzień" 2006, nr 7-8(154-155).

Zielińska M., Postawy młodzieży licealnej wobec nie-petnosprawnych rówieśników, Wyższa Szkoła Pedagogiczna im. T. Kotarbińskiego w Zielonej Górze. Niepublikowana praca magisterska, Zielona Góra 2000.

\section{Podziękowania}

Serdecznie dziękujemy Galerii Labirynt w Lublinie za pomoc w organizacji i przeprowadzeniu badań. Szczególnie wdzięczni jesteśmy Paniom Agacie Sztorc i Emilii Lipie oraz Panu Rafałowi Lisowi. 